DOI: 10.20472/IAC.2019.051.004

\title{
BLESSY AUGUSTINE
}

Institute for Financial Management and Research, India

\section{IMPACT OF EXCHANGE RATE DEPRECIATION ON EXTERNAL INDEBTEDNESS: EVIDENCE FROM A SAMPLE OF EMERGING ECONOMIES}

\begin{abstract}
:
Conventional economic theories based on the Marshall-Lerner condition suggest that exchange rate depreciation is expansionary for an economy as it induces export growth, but the recent wisdom from theories on balance sheet effects explains the ill effects of depreciation (Cespedes et al., 2000; Aghion et al., 2004; Berganza et al., 2004). Amongst various consequences that an exchange rate shock can have on the economy, its impact on country's external indebtedness is humungous. This negative impact becomes particularly relevant for countries with high foreign currency denominated external debt. Countries with high original sin are expected to suffer the most from balance sheet effects, as foreign currency borrowing makes loan repayment more costly in the presence of a depreciating currency. In this paper our attempt is to empirically validate this negative impact of exchange rate depreciation on external debt valuation in a set of developing and emerging economies. The basic trend analysis of the variables show that; for countries that suffers from high original sin, a depreciation in currency is accompanied by rising external indebtedness and/or high debt servicing costs. The study becomes particularly relevant as majority of the emerging or developing economies are facing continuous depreciation of their currencies. The fact that the currency composition can make way for a financial crisis increases the relevance for our study. We also investigate whether countries with high foreign currency denominated debt make use of their exchange rate appreciation episodes to pay off the rising external debt burden. To this end we use the heterogeneous panel data modelling techniques, specifically the pooled mean group (PMG) estimation. We also report the Mean Group (MG) estimation results and the Dynamic fixed effects estimation results. Panel unit root test such as Levin-Lin-Chu test and Im-Pesaran-Shin test are used to find the stationarity of the variables used in the study. We make use of quarterly data for the analysis, which covers the period 2004 - 2017. The results show that there exist a long run relationship between external debt and exchange rate in most of the countries that constitute the panel. At the same time, a depreciation of exchange rate increases external indebtedness in most of these nations significantly, which can lead to situations of financial distress. Depreciating episodes increases the debt servicing cost.
\end{abstract}

\section{Keywords:}

External debt, Exchange rate depreciation, Original Sin, Balance sheet effects, Panel data models

JEL Classification: F30, F34, C23 